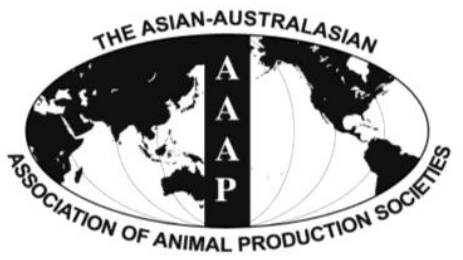

Asian Australas. J. Anim. Sci.

Vol. 26, No. 11 : 1622-1629 November 2013

http://dx.doi.org/10.5713/ajas.2013.13263

Www.ajas.info

pISSN 1011-2367 elSSN 1976-5517

\title{
Separation of Phosvitin from Egg Yolk without Using Organic Solvents
}

\author{
Samooel Jung, Dong Uk Ahn ${ }^{1,2}$, Ki Chang Nam ${ }^{3}$, Hyun Joo Kim, and Cheorun Jo* \\ Department of Agricultural Biotechnology and Research Institute of Agricultural and Life Science, \\ Seoul National University, Seoul 151-921, Korea
}

\begin{abstract}
The objective of this study was to develop a new method to separate phosvitin from egg yolk without using organic solvents. Phosvitin was extracted from yolk granules using $10 \% \mathrm{NaCl}$ or $10 \%\left(\mathrm{NH}_{4}\right)_{2} \mathrm{SO}_{4}$ (final concentration) and then treated with heat to precipitate the lipoproteins from the extracted solution. The optimal $\mathrm{pH}$ for the phosvitin extraction from yolk granules was determined, and the iron-binding ability of the extracted phosvitin (final product) was tested. Adding $10 \%\left(\mathrm{NH}_{4}\right)_{2} \mathrm{SO}_{4}$ disrupted the granules, and the subsequent thermal treatment at $90^{\circ} \mathrm{C}$ for $1 \mathrm{~h}$ precipitated low density and high density lipoproteins, which enabled separation of phosvitin by centrifugation. The phosvitin concentration in the extract was significantly higher when the $\mathrm{pH}$ of the solution was adjusted to $\mathrm{pH} \geq 9$. The purity and recovery rate of phosvitin at the end of the separation process were approximately $78 \%$ and $56 \%$, respectively. The separated phosvitin was confirmed to have ferrous and ferric iron binding ability. The advantages of this new method compared with the traditional methods include no organic solvents and high-priced equipment are needed for the separation. Also, this method is more environment and consumer friendly than that of the traditional methods. (Key Words: Phosvitin, Extraction Method, $\mathrm{pH}$, Iron Binding Ability)
\end{abstract}

\section{INTRODUCTION}

Hen egg yolk phosvitin is a phosphoglycoprotein that forms the structure of yolk granules by making phosphocalcic bridges with high-density lipoprotein (HDL) (Taborsky, 1983). It represents about $7 \%$ of the yolk protein (Mecham and Olcott, 1949). Phosvitin is composed of $\alpha$ - and $\beta$-phosvitin. The $\alpha$-phosvitin is an aggregate of three or four sub-units of 35 to $40 \mathrm{kDa}$ and the $\beta$-phosvitin is an aggregate of four or five subunits of $45 \mathrm{kDa}$ (Anton et al., 2007). These have a characteristic amino acid composition, which is approximately $50 \%$ serine, and most of which are phosphorylated (Clark, 1985). This specific structure makes phosvitin a potent metal chelator. Typically, phosvitin isolated from chicken egg yolk contains 2 to 3 atoms of iron per molecule and two moles of organic phosphorus from

\footnotetext{
* Corresponding Author: Cheorun Jo. Tel: +82-2-880-4804, Fax: +82-2-871-2211, E-mail: cheorun@snu.ac.kr

${ }^{1}$ Department of Animal Science, Iowa State University, Ames, IA 50011 USA.

2 Department of Agricultural Biotechnology, Major in Biomodulation, Seoul National University, Seoul 151-921, Korea.

${ }^{3}$ Department of Animal Science and Technology, Sunchon National University, Suncheon 540-742, Korea.

Submitted May 14, 2013; Accepted Jun. 9, 2013; Revised Jul. 17, 2013
}

phosvitin can bind one mole of iron (Mecham and Olcott, 1949; Taborsky, 1963). Thus, a phosvitin molecule can bind up to 65 to 70 iron molecules under optimal conditions (Taborsky, 1963; Webb et al., 1973).

The metal chelating ability of phosvitin enables it to be used as a functional material. Ishikawa et al. (2004) found that phosvitin and its proteolytic hydrolysates obstruct the generation of iron-catalyzed hydroxyl radicals from the Fenton reaction. And, many researchers have reported that phosvitin inhibited iron-catalyzed lipid oxidation in meat (Lee et al., 2002; Jung et al., 2012a; Jung et al., 2013), and exhibited an antibacterial effect on iron deficient bacteria (Khan et al., 2000; Choi et al., 2004). Additionally, Jung et al. (2012b) suggested phosvitin as melanogenesis inhibitor. For these reasons, phosvitin has received attention, and many studies have attempted to separate phosvitin from chicken egg yolk.

Phosvitin extraction and purification methods reported in previous studies used organic solvents, such as ether, a combination of chloroform and methanol, a combination of hexane and ethanol, or ethanol to remove lipids and phospholipids from yolk granules (Heald and McLachlan, 1963; Wallace and Morgan, 1986; Losso and Nakai, 1994). Although these methods separate phosvitin from chicken egg yolk, the extracted phosvitins have limited use because 
of the solvents used, and these methods are relatively complicated. Furthermore, some of the solvents used can modify phosvitin structure or decrease the recovery of phosvitin (Castellani et al., 2003; Ko et al., 2011). Improved methods for separating phosvitin from chicken egg yolk have been introduced recently. Highly purified phosvitin (98\%) with a high recovery rate $(85 \%)$ was produced by an isolation method based on the insolubility of $\mathrm{Mg}^{2+} /$ phosvitin salt followed by ion-exchange chromatography (Castellani et al., 2003). Also, phosvitin was successfully separated using ethanol and $\mathrm{NaCl}$ with a $96 \%$ recovery rate (Ko et al., 2011). These two methods can be used to develop large-scale production of phosvitin, but these methods still use high priced equipment or organic solvents.

Thermal precipitation is a precipitation technique used to isolate and purify proteins. Proteins denatured by thermal treatments can be removed by mild centrifugation (Burgess, 2009). Yolk granules contain $70 \%$ high density lipoprotein (HDL), 16\% phosvitin, and 12\% low-density lipoproteins (LDL) with different thermal stabilities (Anton et al., 2000). Phosvitin and $\beta$-HDL are not affected by thermal treatments up to $82^{\circ} \mathrm{C}$, whereas LDL and $\alpha$-HDL are denatured at 72 and $76^{\circ} \mathrm{C}$, respectively. Phosvitin can be extracted from yolk granules by disintegrating granule structure using 0.5 M NaCl (Le Denmat et al., 1999; Anton et al., 2000). Additionally, the extracted phosvitin does not aggregate and iron binding ability is not influenced when the solution is heated at $90^{\circ} \mathrm{C}$ for $60 \mathrm{~min}$ (Castellani et al., 2004).

Therefore, we hypothesized that phosvitin could be extracted with salt and purified by thermal treatment without using organic solvents. The phosvitin separation procedure using thermal treatment is simpler than previously developed methods and appropriate for largescale phosvitin production. The objective of this study was to develop a new separation method for phosvitin from egg yolk without using organic solvents.

\section{MATERIALS AND METHODS}

\section{Chemicals}

Chicken eggs were obtained from a local market (Daejeon, Korea). Phosvitin standard, acrylamide, N,N'methylene-bis-acrylamide, tris (hydroxymethyl) aminomethane (Tris), sodium dodecyl sulfate (SDS), ammonium persulfate, N,N,N',N'-tetramethyleethylenediamine (TEMED), glycine, glycerin, Coomassie Brilliant Blue G-250, aluminum nitrate, and Tween 20 were obtained from Sigma-Aldrich (St. Louis. MO, USA). Protein $2 \times$ sample buffer was obtained from Elpis-Biotech (Daejeon, Korea). Sodium chloride, potassium chloride, and ammonium sulfate were obtained from Junsei Chemical
(Tokyo, Japan). Enhanced chemiluminescence (ECL) plus Western blotting detection reagent was obtained from GE Healthcare (Buckinghamshire, UK). Mouse monoclonal $\mathrm{IgG} 2 \mathrm{a}$ and goat anti-mouse IgG-horseradish peroxidase were obtained from Santa Cruz Biotechnology (Santa Cruz, CA, USA). Prestained protein markers were obtained from iNtRon Biotechnology (Sungnam, Korea).

\section{Phosvitin extraction}

Yolk was separated from egg white, and carefully rolled on a paper towel to remove all egg white. Then, the egg yolk membranes and chalaza were removed by filtering through a 2,000 $\mu \mathrm{m}$ testing sieve (Chung Gye Sang Gong Sa, Seoul, Korea). The filtered egg yolk was homogenized with two volumes of cold $0.17 \mathrm{M} \mathrm{NaCl}$, and centrifuged at $4,070 \times g$ for $30 \mathrm{~min}$ at $4^{\circ} \mathrm{C}$. The precipitant was collected and re-suspended in two volumes of cold $0.17 \mathrm{M} \mathrm{NaCl}$, homogenized, and centrifuged at $4,070 \times g$ for $30 \mathrm{~min}$. The precipitant containing yolk granules was collected, and homogenized with five volumes of $12 \% \mathrm{NaCl}$ or $12 \%$ $\left(\mathrm{NH}_{4}\right)_{2} \mathrm{SO}_{4}$ (final concentration was $10 \%$ ). The disrupted granules solution was subjected to thermal treatment in a water bath at $70,80,85$, or $90^{\circ} \mathrm{C}$ for $1 \mathrm{~h}$. After heating, the sample solutions were diluted $(1: 6, \mathrm{v} / \mathrm{v})$ with distilled water, and the $\mathrm{pH}$ of the sample solutions was adjusted to $\mathrm{pH} 4.0$ to 12.0 using $6 \mathrm{~N} \mathrm{HCl}$ or $10 \mathrm{~N} \mathrm{NaOH}$. After stirring for 30 $\mathrm{min}$, the homogenates were centrifuged at $4,070 \times g$ for 30 $\min$ at $4^{\circ} \mathrm{C}$. The supernatant was filtered through filter paper (Whatman No.1) to remove floating particles. The filtrate was concentrated and desalted using an ultrafiltration system (Quixstand Benchtop System using a membrane column with a $10 \mathrm{kDa}$ molecular weight cut-off; GE Healthcare, Waukesha, WI, USA), and then centrifuged at $4,070 \times g$ for $30 \mathrm{~min}$ at $4{ }^{\circ} \mathrm{C}$. The supernatant was collected and lyophilized (Figure 1).

\section{Sodium dodecyl sulfate-polyacrylamide gel electrophoresis (SDS-PAGE)}

SDS-PAGE was performed using a $10 \%$ polyacrylamide gel containing $30 \%$ acrylamide solution, $1.5 \mathrm{M}$ Tris- $\mathrm{HCl}$ $(\mathrm{pH}$ 8.8), $0.5 \mathrm{M}$ Tris- $\mathrm{HCl}(\mathrm{pH}$ 6.8), $10 \%$ ammonium persulfate, and TEMED. The extracted protein solution was mixed with the same volume of $2 \times$ sample buffer composed of $125 \mathrm{mM}$ Tris- $\mathrm{HCl}$ (pH 6.8), 20\% glycerol, 2\% SDS, $2 \%$ mercaptoethanol, and $0.02 \%$ bromophenol blue, and heated at $95^{\circ} \mathrm{C}$ on a heating block for 2 min. Pre-stained protein markers ( 9 to $198 \mathrm{kDa}$ ) were used as molecular markers. Electrophoretic separation was performed with the pageRun system (AE-6531 mPAGE, ATTO Co., Tokyo, Japan) by applying $40 \mathrm{~mA}$ for $40 \mathrm{~min}$. The running buffer was composed of $25 \mathrm{mM}$ Tris, $0.1 \%$ SDS, and $192 \mathrm{mM}$ glycine. Proteins in the gels were stained with Coomassie Brilliant 


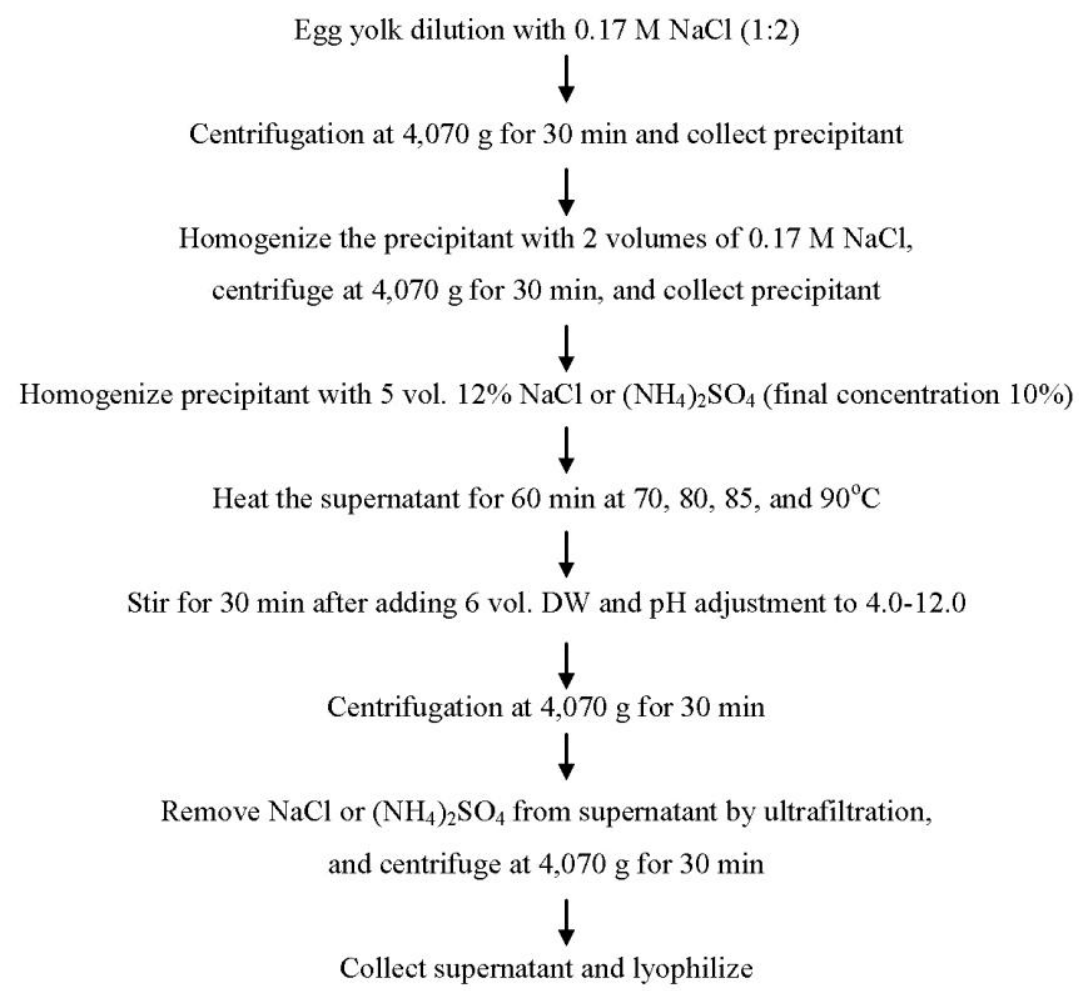

Figure 1. Procedure for purification of phosvitin from egg yolk.

Blue containing $0.1 \mathrm{M}$ aluminum nitrate, and then destained in a $10 \%$ acetic acid solution. The stained gel was scanned using a GS-710 (Bio-Rad Laboratories Inc, Hercules, CA, USA) densitometer at an optical resolution of $63.5 \mu \mathrm{m} /$ pixel and then analyzed by Image Master 2D Platinum v5.0 (GE Healthcare, formerly Amersham Biosciences). The relative phosvitin composition in the protein solution was estimated from band intensity (pixel intensity $\times$ band area).

\section{Iron-binding ability of phosvitin}

The iron-binding ability of the isolated phosvitin was determined using a modified ferrozine method (Riemer and Hoepken, 2004). A mixture of $3.3 \mathrm{~mL}$ distilled water, $50 \mu \mathrm{L}$ $3.0 \mathrm{mM} \mathrm{FeCl}$ or $3.0 \mathrm{mM} \mathrm{FeCl}_{2} .4 \mathrm{H}_{2} \mathrm{O}$ in distilled water, and $50 \mu \mathrm{L}$ phosvitin solution were placed in a $15 \mathrm{~mL}$ conical tube. The mixture was left at room temperature for $1 \mathrm{~min}$. Next, $0.4 \mathrm{~mL}$ of $5 \mathrm{mM}$ ferrozine was blended with $0.2 \mathrm{~mL}$ $1 \%$ ascorbic acid in distilled water and added to the tubes. After 5 min incubation at room temperature, the final color change was monitored using a spectrophotometer (DU530, Beckman Instruments Inc., Fullerton, CA, USA) at $562 \mathrm{~nm}$ using distilled water as a blank. Iron binding ability was calculated with the following equation:

Iron binding ability $(\%)=\left[\left(\mathrm{A}_{0}-\mathrm{A}_{1}\right) / \mathrm{A}_{0}\right] \times 100$

Where, $\mathrm{A}_{0}$ indicates the absorbance of the sample solution without phosvitin and $\mathrm{A}_{1}$ indicates the absorbance of the sample solution with phosvitin.

\section{Western blotting}

Proteins in the SDS-PAGE gel were transferred to pure nitrocellulose membranes (Trans-Blot Transfer medium; Bio-Rad) using the Trans-Blot apparatus (Bio-Rad). The transfer buffer was composed of $24 \mathrm{mM}$ Tris, $192 \mathrm{mM}$ glycine, and $20 \%(\mathrm{v} / \mathrm{v})$ methanol. After transfer, the membranes was blocked with $5 \%$ nonfat dry milk (w/v) in TBS-T solution ( $\mathrm{pH} 7.4$ ) composed of $24.8 \mathrm{mM}$ Tris, 137 $\mathrm{mM}$ sodium chloride, $2.7 \mathrm{mM}$ potassium chloride, and $0.05 \%$ Tween 20 for $1 \mathrm{~h}$ at room temperature. After blocking, the membrane was washed six times (10 $\mathrm{min} /$ wash) with TBS-T and then incubated at room temperature for $1 \mathrm{~h}$ with phosvitin primary antibody (mouse monoclonal IgG2a, Santa Cruz Biotechnology) diluted with TBS-T at the ratio of $1: 2,500$. The membrane was rewashed three times (10 $\mathrm{min} / \mathrm{wash})$ with TBS-T for removing primary antibody and then incubated at room temperature for $1 \mathrm{~h}$ with the secondary antibody (goat antimouse IgG-horseradish peroxidase, Santa Cruz Biotechnology) diluted with TBS-T at the ratio of 1:10,000. After the secondary antibody incubation, the membrane was washed three times (10 $\mathrm{min} / \mathrm{wash})$, and the detection procedure was carried out in a darkroom using an ECL kit (ECL Plus Western Blotting Detection Reagents, RPN2132, GE Healthcare). The detection reagent was poured onto the 
membrane and incubated for $1 \mathrm{~min}$. The detection reagent was drained off, and the membrane was exposed to a sheet of diagnostic film (AGFA, Mortsel, Belgium) in a film cassette for $1 \mathrm{~min}$.

\section{Purity of extracted phosvitin}

Phosvitin contains 8 to $10 \%$ phosphorus and $6.5 \%$ carbohydrates. Thus, phosvitin contains $13 \%$ nitrogen (Shainkin and Perlmann, 1971; Guérin-Dubiard et al., 2002). The purity of extracted phosvitin was estimated by multiplying nitrogen content X 7.69. Nitrogen content of the phosvitin was determined by Kjeldahl method with automatic Kjeldahl analyzers (Gerhardt GmbH \& Co. KG, Germany).

\section{Statistical analysis}

All experimental treatments were performed in triplicate. An analysis of variance was performed on raw data, and the mean values and standard deviations were calculated using Statistical Analysis System software (SAS Institute, Cary, NC, USA). Differences among the means were determined by Duncan's multiple range test and $\mathrm{p}<0.05$ was considered significant.

\section{RESULTS AND DISCUSSIONS}

\section{Separation of egg yolk plasma and granules}

To separate egg yolk plasma and granules, egg yolk was diluted with $0.17 \mathrm{M} \mathrm{NaCl}$ and then centrifuged at 4,070 g for $30 \mathrm{~min}$. The supernatant plasma and precipitated granules were diluted in $1 \% \mathrm{NaCl}$ and delipidated using acetone to clearly identify the protein composition on the SDS-PAGE gel. The SDS-PAGE results are shown in

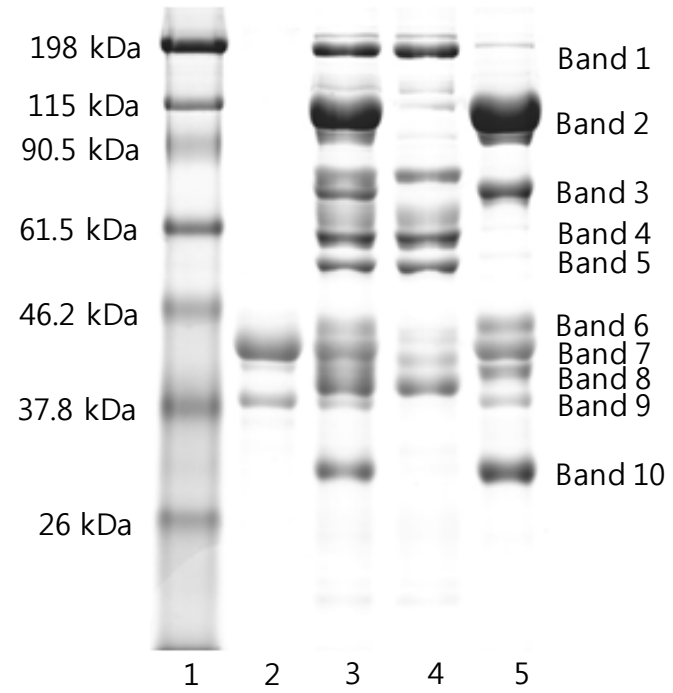

Figure 2. SDS-PAGE profiles of delipidated proteins from egg yolk fractions. Lane 1, molecular weight markers; lane 2, phosvitin standard; lane 3, whole egg yolk; lane 4, egg yolk plasma; lane 5, egg yolk granules.
Figure 2. The granules contained LDLs [bands 1 (203 kDa), $4(62 \mathrm{kDa})$, and $5(55 \mathrm{kDa})$ ], HDLs [bands $2(110 \mathrm{kDa}), 3$ $(78 \mathrm{kDa})$, and $10(31 \mathrm{kDa})$ ], and phosvitin [bands 7, 8, and 9 (40 to $45 \mathrm{kDa})$ ] which were identical to standard phosvitin (Guilmineau et al., 2005). These results confirmed that phosvitin has several components $(\alpha 1, \alpha 2$, and $\beta$ phosvitin) and that the major component is $\beta$-phosvitin (45 kDa) (Castellani et al., 2003; Ko et al., 2011). However, other studies have reported that the molecular weight of phosvitin is 35 or $55 \mathrm{kDa}$ as a single band (Jiang and Mine, 2000; Guilmineau et al., 2005). A protein (band 6) located near $\beta$-phosvitin was not reported in previous studies (Jiang and Mine, 2000; Castellaniet al., 2003; Guilmineau et al., 2005; Ko et al., 2011), but it was thought to be phosvitin because it appeared on the SDS-PAGE results of standard and extracted phosvitin (Figure 7). Several protein bands were identical between plasma and granules. Guilmineau et al. (2005) reported that the protein bands at 203 and $55 \mathrm{kDa}$ in plasma are associated with $\gamma$-livetin and a part of $\alpha$ livetin, respectively. The plasma protein bands at 40 to 45 kDa could be $\beta$-livetin (Hatta et al., 2008).

Optimal temperature for extracting phosvitin in the disrupted granule solution

The extracted phosvitin solutions were diluted to decrease the concentration of $\mathrm{NaCl}$ or $\left(\mathrm{NH}_{4}\right)_{2} \mathrm{SO}_{4}$ to approximately $1.5 \%$, because HDLs become insoluble when the ionic strength is $<0.3 \mathrm{M} \mathrm{NaCl}$ (about 1.8\%) (Anton et al., 2007). However $\mathrm{NaCl}$ or $\left(\mathrm{NH}_{4}\right)_{2} \mathrm{SO}_{4}$ was used in the present study at the same concentrations although the ionic strength of $\left(\mathrm{NH}_{4}\right)_{2} \mathrm{SO}_{4}$ is higher than that of $\mathrm{NaCl}$ at the same concentration. The proteins in the supernatants after

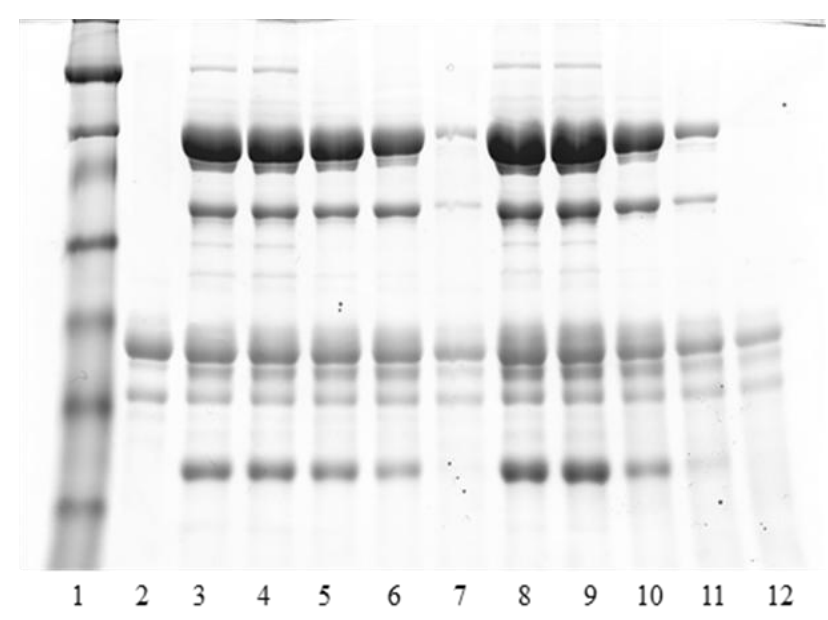

Figure 3. SDS-PAGE profiles of the extracted solutions using thermal treatment to disrupt the granules. Lane 1, molecular weight markers; lane 2, phosvitin standard; lanes 3-7, thermal treatments at $20,70,80,85$, or $90^{\circ} \mathrm{C}$ with $\mathrm{NaCl}$; lanes $8-12$, thermal treatments at $20,70,80,85$, or $90^{\circ} \mathrm{C}$ with $\left(\mathrm{NH}_{4}\right)_{2} \mathrm{SO}_{4}$. 
centrifugation of the diluted solution were separated by SDS-PAGE (Figure 3).

The LDL apo-protein bands disappeared, and the intensity of the HDL apo-protein bands in the extracted solutions decreased gradually as the heating temperature increased to $80^{\circ} \mathrm{C}$ or higher regardless $\mathrm{NaCl}$ or $\left(\mathrm{NH}_{4}\right)_{2} \mathrm{SO}_{4}$ treatment. Thermal treatment at $70^{\circ} \mathrm{C}$, however, had no effect on denaturing the granular proteins. This result agreed with previous studies suggesting that granular proteins, except for phosvitin and $\beta$-HDL, in the disrupted granule solution containing $0.5 \mathrm{M} \mathrm{NaCl}$, were denatured by thermal treatments over 72 and $76^{\circ} \mathrm{C}$ (Le Denmat et al., 1999; Anton et al., 2000). However, in this study, the intensity of $\beta$-HDL bands decreased following thermal treatment at $80^{\circ} \mathrm{C}$ with $\left(\mathrm{NH}_{4}\right)_{2} \mathrm{SO}_{4}$, and these bands shrunk remarkably when disrupted granule solutions were subjected to thermal treatment at $90^{\circ} \mathrm{C}$ with $\mathrm{NaCl}$ and $85^{\circ} \mathrm{C}$ with $\left(\mathrm{NH}_{4}\right)_{2} \mathrm{SO}_{4}$. Particularly, $90^{\circ} \mathrm{C}$ thermal treatment of samples extracted with $\left(\mathrm{NH}_{4}\right)_{2} \mathrm{SO}_{4}$ precipitated all $\beta$-HDL from the samples.

The phosvitin composition among proteins in the extracted solution was expressed as the relative intensity of phosvitin bands in relation to the sum of all band intensity in each lane (Figure 4). The $85^{\circ} \mathrm{C}$ thermal treatment with $\left(\mathrm{NH}_{4}\right)_{2} \mathrm{SO}_{4}$ or the $90^{\circ} \mathrm{C}$ treatment with both $\mathrm{NaCl}$ and $\left(\mathrm{NH}_{4}\right)_{2} \mathrm{SO}_{4}$ significantly increased the proportion of phosvitin among proteins in the extracted solution due to denaturation and precipitation of all other granular proteins $(\mathrm{p}<0.05)$. Phosvitin composition was the highest in samples extracted with $\left(\mathrm{NH}_{4}\right)_{2} \mathrm{SO}_{4}$ and then treated at $90^{\circ} \mathrm{C}$ when compared with lower thermal treatments or $\mathrm{NaCl}$ extracts $(\mathrm{p}<0.05)$. The $\mathrm{NaCl}$ or $\left(\mathrm{NH}_{4}\right)_{2} \mathrm{SO}_{4}$ concentrations necessary to disrupt phosphocalcic bridges between phosvitin and

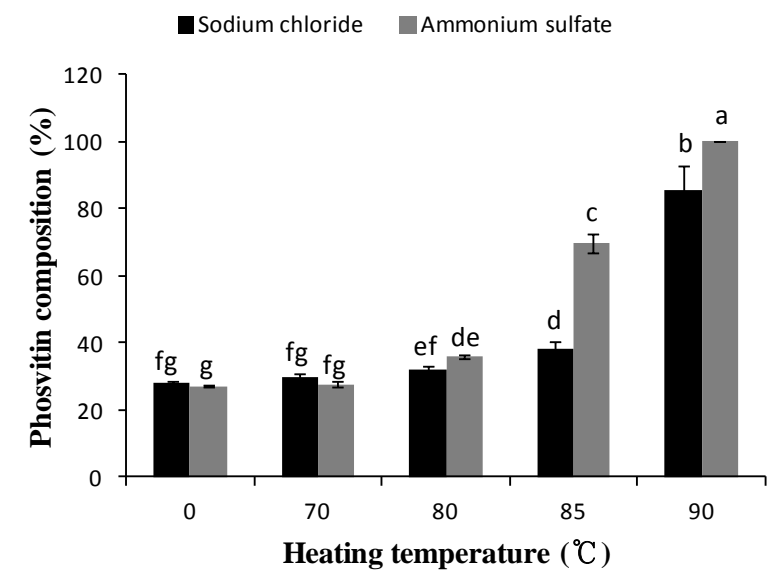

Figure 4. Phosvitin composition (\%) calculated as relative phosvitin band intensity (pixel intensity $\times$ band area) among proteins in the extracted solution after thermal treatment to disrupt the granules. ${ }^{\mathrm{a}-\mathrm{g}}$ Different letters among treatments differ significantly $(\mathrm{p}<0.05)$.
HDL were adapted from a previous study (Ko et al., 2011). Ko et al. (2011) suggested that the phosvitin extraction yield from delipidated granules homogenates with $10 \%$ $\left(\mathrm{NH}_{4}\right)_{2} \mathrm{SO}_{4}$ is significantly higher than that with $4,15,20$, or $25 \%\left(\mathrm{NH}_{4}\right)_{2} \mathrm{SO}_{4}$. Additionally, the purity of the extracted phosvitin using $10 \%\left(\mathrm{NH}_{4}\right)_{2} \mathrm{SO}_{4}$ is significantly higher than that of the $10 \% \mathrm{NaCl}$, even if the phosvitin yield is higher when $10 \% \mathrm{NaCl}$ was used. The present work agreed with the results of Ko et al. (2011), and the difference in purity might be due to the difference in salting-out ability between $\mathrm{NaCl}$ and $\left(\mathrm{NH}_{4}\right)_{2} \mathrm{SO}_{4}$. Ammonium sulfate is a strong salting-out agent for proteins and its salting out ability is higher than that of $\mathrm{NaCl}$ (Dumetz et al., 2008).

From the results, the optimal temperature for removing other proteins from the phosvitin extracts was $90^{\circ} \mathrm{C}$, and the use of the $\left(\mathrm{NH}_{4}\right)_{2} \mathrm{SO}_{4}$ for disrupting granules was more effective to remove other proteins from the phosvitin extracts than was $\mathrm{NaCl}$.

\section{Effect of $\mathrm{pH}$ on phosvitin solubility in the $\left(\mathrm{NH}_{4}\right)_{2} \mathrm{SO}_{4}$ - extracted solution after the $90^{\circ} \mathrm{C}$ thermal treatment}

Protein solubility is very important for extracting proteins because an increase in protein solubility improves protein yields. Protein solubility in an extracted solution can be increased by adding promoters such as ionic compounds, salts, detergents, and osmolytes (Golovanov et al., 2004).

Phosvitin solubility was expressed as phosvitin composition of the extracted solution (Figure 5). The initial $\mathrm{pH}$ of the extracted solution, which contained approximately $1.5 \% \quad\left(\mathrm{NH}_{4}\right)_{2} \mathrm{SO}_{4}$, was about $6.6 \pm 0.1$. Phosvitin solubility was affected by the $\mathrm{pH}$ of the extracting solution. Increasing the $\mathrm{pH}$ of the extracting solution above the initial $\mathrm{pH}$ significantly increased phosvitin solubility $(\mathrm{p}<0.05)$. In contrast, decreasing the $\mathrm{pH}$ of the extracting solution below the initial $\mathrm{pH}$ significantly decreased

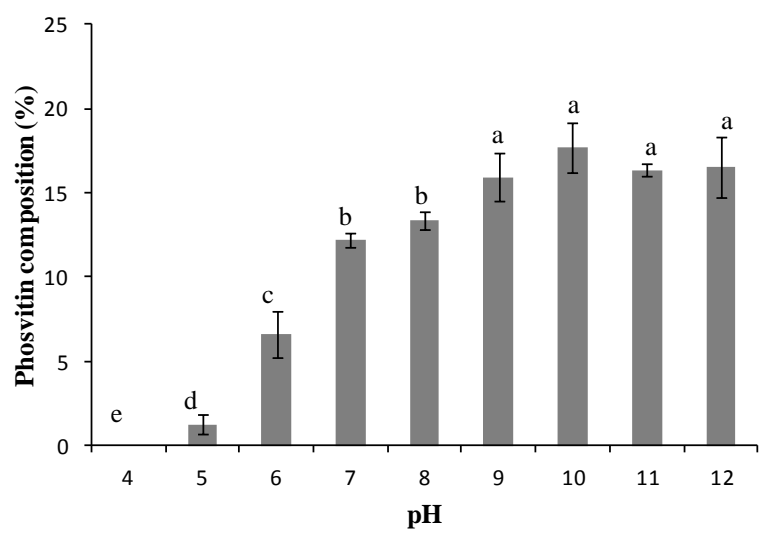

Figure 5. Phosvitin composition (\%) calculated as relative phosvitin band intensity (pixel intensity $\times$ band area) of $\left(\mathrm{NH}_{4}\right)_{2} \mathrm{SO}_{4}$ extracted solution after $90^{\circ} \mathrm{C}$ thermal treatment among different $\mathrm{pH} .{ }^{\mathrm{a}-\mathrm{e}}$ Different letters among $\mathrm{pH}$ treatments differ significantly $(\mathrm{p}<0.05)$. 
phosvitin solubility $(\mathrm{p}<0.05)$. Phosvitin solubility was the highest at $\mathrm{pH} \geq 9$ and the lowest at $\mathrm{pH} 4$, which is the isoelectric point of phosvitin. However, the $\beta$-HDL band started to appear at $\mathrm{pH} \geq 10$ on the SDS-PAGE gel (data not shown). Previous studies reported that most egg yolk proteins are soluble in saline buffer $(0.56 \mathrm{M} \mathrm{NaCl}$ at $\mathrm{pH} 9)$, and that phosvitin solubility gradually increases when the $\mathrm{pH}$ is increased from 4 to 10 (Guilmineau et al., 2005; Chay Pak Ting et al., 2010). However, Castellani et al. (2003) reported that the highest phosvitin solubility (97.7\%) was observed at $\mathrm{pH} 7$ with low $\mathrm{MgSO}_{4}$ concentrations. The reason for the different $\mathrm{pH}$ effects on phosvitin solubility could be due to differences in salt concentrations or the kind of salts used.

This result suggested that adjusting $\mathrm{pH}$ of the extracting solution to 9 could improve the phosvitin yield, although it required a larger amount of $\mathrm{NaOH}$ because of the buffering ability of $\left(\mathrm{NH}_{4}\right)_{2} \mathrm{SO}_{4}$ at $\mathrm{pH}>8$.

\section{Western blotting}

After centrifugation (at 4,070 $\mathrm{g}$ for $30 \mathrm{~min}$ ) of $\mathrm{pH} 9$ phosvitin solution extracted by $\left(\mathrm{NH}_{4}\right)_{2} \mathrm{SO}_{4}$ with the $90^{\circ} \mathrm{C}$ thermal treatment, the supernatant was concentrated and desalted using ultrafiltration, and then lyophilized to obtain the final product. The SDS-PAGE result showed that the final phosvitin sample with five repetitions were similar to standard phosvitin in quality (Figure 6). However, a previous study indicated that it is difficult to conclude whether the band is phosvitin using the SDS-PAGE pattern of extracted phosvitin alone, because some proteins in egg yolk have similar molecular weights to phosvitin (Ko et al., 2011). For this reason, the extracted phosvitins were identified by Western blotting. The result of Western blotting confirmed that the extracted phosvitins were identical to standard phosvitin.

\section{Yield, purity, and iron-binding ability of the separated phosvitin}

The yields and purities of the extracted phosvitin with five repetitions using this method are shown in Table 1. The average yield of extracted phosvitin from the current method was $56 \%$, and the average purity was $78 \%$. The recovery rate of phosvitin from egg yolk was calculated using the value (12 mg phosvitin/g yolk) reported by Juneja and Kim (1997). In the present study, the granules disrupted

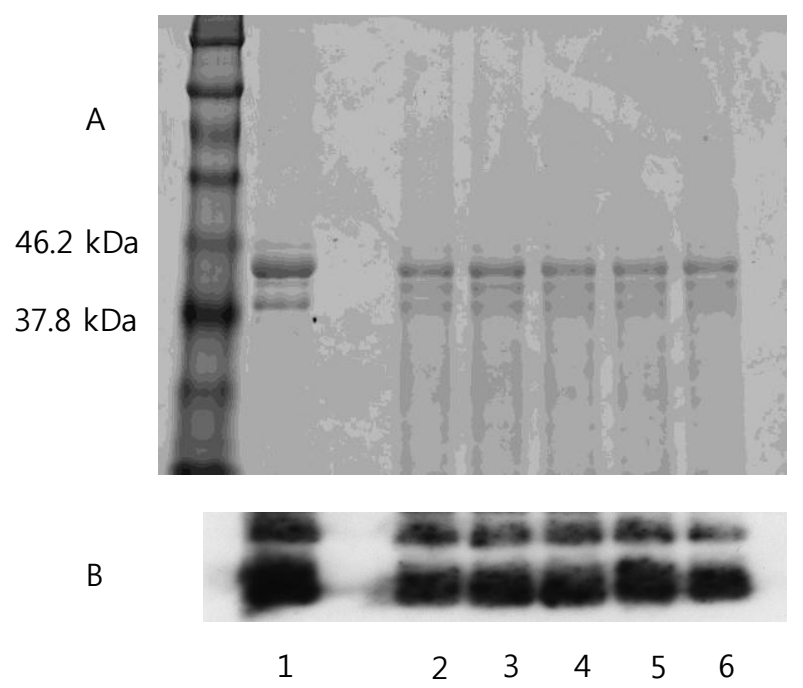

Figure 6. SDS-PAGE profiles (A) and Western blotting (B) of extracted phosvitins (final products). Lane 1, phosvitin standard; lanes 2-6, extracted phosvitins.

by $10 \%\left(\mathrm{NH}_{4}\right)_{2} \mathrm{SO}_{4}$ were heated at $90^{\circ} \mathrm{C}$ to precipitate other proteins from the granules. As a result, only phosvitin bands are shown in the extracted solution after the $90^{\circ} \mathrm{C}$ heat treatment (Figure 3). However, the intensity of the phosvitin bands in the extracted solution after heating at $90^{\circ} \mathrm{C}$ decreased when compared with that after heating at $70^{\circ} \mathrm{C}$ (data not shown). This may be the consequence of coprecipitation of some of the phosvitin with other proteins, which lead to a lower phosvitin recovery rate.

The extracted phosvitin showed approximately 22.2 and $50.7 \%$ ferrous and ferric iron binding ability, respectively, even though these percentages were significantly lower than those of the standard phosvitin $38.2 \%$ of ferrous iron and $63.4 \%$ of ferric iron) $(\mathrm{p}<0.05)$. This result agreed with that of a previous study, which suggested that phosvitin has a higher affinity for ferric iron than ferrous iron (Ishikawa et al., 2004). The iron-binding capacity of phosvitin is about 65 to 70 moles of iron per mole of phosvitin, which can inhibit lipid oxidation catalyzed by the Fenton reaction $\left(\mathrm{Fe}^{2+} / \mathrm{H}_{2} \mathrm{O}_{2}\right)$ (Taborsky, 1983; Ishikawa et al., 2004). Ishikawa et al. (2004) suggested that phosvitin has higher antioxidant activity than that of other iron-binding proteins such as transferrin and ferritin. Therefore, extracted phosvitin could be used as an antioxidant.

The $\mathrm{pH}$ of the extracted solution was $6.6 \pm 0.1$ after

Table 1. Yield, purity, and iron binding ability of phosvitin obtained by the developed extraction method

\begin{tabular}{|c|c|c|c|c|c|c|}
\hline & St $\mathrm{P}^{\mathrm{a}}$ & $\mathrm{Ex} P 1^{\mathrm{b}}$ & Ex P 2 & Ex P 3 & Ex P 4 & Ex P 5 \\
\hline Yield (g/kg egg yolk) & - & 8.14 & 8.60 & 8.96 & 8.60 & 8.70 \\
\hline Purity (\%) & - & $79.4 \pm 0.20$ & $78.4 \pm 0.15$ & $80.7 \pm 0.35$ & $76.3 \pm 0.50$ & $76.7 \pm 1.20$ \\
\hline Iron binding ability $\left(\%, \mathrm{Fe}^{2+}\right)$ & $38.2 \pm 0.83$ & $23.8 \pm 0.80$ & $22.2 \pm 1.09$ & $22.1 \pm 0.43$ & $21.5 \pm 1.25$ & $21.5 \pm 0.65$ \\
\hline Iron binding ability $\left(\%, \mathrm{Fe}^{3+}\right)$ & $63.4 \pm 1.22$ & $49.0 \pm 0.30$ & $50.4 \pm 0.30$ & $52.6 \pm 0.95$ & $49.9 \pm 0.14$ & $51.4 \pm 0.29$ \\
\hline
\end{tabular}

${ }^{\mathrm{a}}$ Standard phosvitin obtained from Sigma-Aldrich. ${ }^{\mathrm{b}}$ Separated phosvitins. 
desalting by ultrafiltration. Ko et al. (2011) reported that $10 \%\left(\mathrm{NH}_{4}\right)_{2} \mathrm{SO}_{4}$ used to extract phosvitin from egg yolk granules after removing lipids with ethanol had the highest recovery rate at $\mathrm{pH} 4$. Thus, the $\mathrm{pH}$ of the extracted solution after desalting was adjusted to 4,5 , and 6 , centrifuged at $4,070 \times \mathrm{g}$ for $30 \mathrm{~min}$, and the supernatants were lyophilized. However the extracted phosvitin recovery rates were not significantly improved by this $\mathrm{pH}$ adjustment. Additionally, the iron-binding ability of the separated phosvitin at $\mathrm{pH} 4$ was significantly lower than that at $\mathrm{pH} 6.6 \pm 0.1$ (data not shown). This result confirmed that the iron-binding ability of phosvitin was the highest in neutral $\mathrm{pH}$ (6.5) conditions (Castellani et al., 2004).

\section{CONCLUSION}

Our results suggest that separation of phosvitin from egg yolk can be done without using organic solvents, but that a thermal treatment $\left(85\right.$ to $\left.90^{\circ} \mathrm{C}\right)$ is needed to remove impurities from the $10 \% \mathrm{NaCl}$ or $\left(\mathrm{NH}_{4}\right)_{2} \mathrm{SO}_{4}$ extracts. Although the recovery rate of phosvitin from yolk granules was lower than that from other methods, this method was relatively simple, cost-effective, environmentally friendly, and suited for large-scale production. The extracted phosvitin was confirmed to have very high ferrous and ferric iron-binding ability, which is important for its applications in food and other industries.

\section{ACKNOWLEDGEMENTS}

This work was supported by a grant from the NextGeneration BioGreen 21 Program (No. PJ0081330), Rural Development Administration, Republic of Korea.

\section{REFERENCES}

Anton, M., O. Castellani, and C. Guérin-Dubiard. 2007. Phosvitin. In: Bioactive Egg Compounds (Ed R. Huopalahti, R. LópezFañdino, M. Anton and R. Schade). Springer Press, Europe. pp $17-24$.

Anton, M., H. Le Denmat, and G. Gandemer. 2000. Thermostability of hen egg yolk granules: Contribution of native structure of granules. J. Food Sci. 65:581-584.

Burgess, R. R. 2009. Protein precipitation techniques. In Methods in Enzymology: Guide to protein purificaion 2nd (Ed. R. R. Burgess and M. P. Deutscher). Academic Press, USA. pp. 463:331-342.

Castellani, O., C. Guerin-Dubiard, E. David-Briand, and M. Anton. 2004. Influence of physicochemical conditions and technological treatments on the iron binding capacity of egg yolk phosvitin. Food Chem. 85:569-577.

Castellani, O., V. Martinet, E. David-Briand, C. Guerin-Dubiard, and M. Anton. 2003. Egg yolk phosvitin: preparation of metalfree purified protein by fast protein liquid chromatography using aqueous solvents. J. Chromatogr. B 791:273-284.

Chay Pak Ting, B. P., Y. Pouliot, L. R. Juneja, T. Okubo, S. F. Gauthier, and Y. Mine. 2010. On the use of ultrafiltration for the concentration and desalting of phosvitin from egg yolk protein concentrate. Int. J. Food Sci. Technol. 45:1633-1640.

Clark, R. C. 1985. The primary structure of avian phosvitins. Contributions through the Edman degradation of methylmercaptovitins prepared from the constituent phosphoproteins. Int. J. Biochem. Cell B 17:983-988.

Dumetz, A. C., R. A. Lewus, A. M. Lenhoff, and E. W. Kaler. 2008. Effects of ammonium sulfate and sodium chloride concentration on PEG/protein liquid-liquid phase separation. Langmuir 24:10345-10351.

Golovanov, A. P., G. M. Hautbergue, S. A. Wilson, and L. Y. Lian. 2004. A simple method for improving protein solubility and long-term stability. J. Am. Chem. Soc. 126:8933-8939.

Guerin-Dubiard, C., M. Anton, A. Dhene-Garcia, V. Martinet, and G. Brule. 2002. Hen egg and fish egg phosvitins: composition and iron binding properties. Eur. Food Res. Technol. 214:460464.

Guilmineau, F., I. Krause, and U. Kulozik. 2005. Efficient analysis of egg yolk proteins and their thermal sensitivity using sodium dodecyl sulfate polyacrylamide gel electrophoresis under reducing and nonreducing conditions. J. Agric. Food Chem. 53:9329-9336.

Hatta, H., M. P. Kapoor, and L. R. Juneja. 2008. Bioactive components in egg yolk. In: Egg bioscience and biotechnology (Ed. Y. Mine). Wiley-Interscience, New Jersey. pp. 185-237.

Heald, P. J. and P. M. McLachlan. 1963. Isolation of phosvitin from the plasma of the laying hen. Biochem. J. 87:571-576.

Ishikawa, S., Y. Yano, K. Arihara, and M. Itoh. 2004. Egg yolk phosvitin inhibits hydroxyl radical formation from the Fenton reaction. Biosci. Biotechnol. Biochem. 68:1324-1331.

Jiang, B. and Y. Mine. 2000. Preparation of novel functional oligophosphopeptides from hen egg yolk phosvitin. J. Agric. Food Chem. 48:990-994.

Juneja, L. R. and M. Kim. 1997. Egg yolk proteins. In: Hen eggsTheir Basic and Applied Science (Ed. T. Yamamoto, L. R. Juneja, H. Hatta, and M. Kim). CRC press, New York. pp. 5771.

Jung, S., C. Jo, M. Kang, D. U. Ahn, and K. C. Nam. 2012a. Elucidation of antioxidant activity of phosvitin extracted from egg yolk using ground meat. Korean J. Food Sci. An. 32:162167.

Jung, S., D. H. Kim, J. H. Son, K. Nam, D. U. Ahn, and C. Jo. $2012 \mathrm{~b}$. The functional property of egg yolk phosvitin as a melanogenesis inhibitor. Food Chem. 135:993-998.

Jung, S., K. C. Nam, D. U. Ahn, H. J. Kim, and C. Jo. 2013. Effect of phosvitin on lipid and protein oxidation in ground beef treated with high hydrostatic pressure. Meat Sci. 95:8-13.

Ko, K. Y., K. Nam, C. Jo, E. J. Lee, and D. U. Ahn. 2011. A simple and efficient method for preparing partially purified phosvitin from egg yolk using ethanol and salts. Poult. Sci. 90:10961104.

Le Denmat, M., M. Anton, and G. Gandemer. 1999. Protein denaturation and emulsifying properties of plasma and granules of egg yolk as related to heat treatment. J. Food Sci. 64:194-197. 
Lee, S. K., J. H. Han, and E. A. Decker. 2002. Antioxidant activity of phosvitin in phosphatidylcholine liposomes and meat model systems. J. Food Sci. 67:37-41.

Losso, J. N. and S. A. Nakai. 1994. A simple procedure for the isolation of phosvitin from chicken egg yolk. In: Egg uses a processing technologies (Ed. J. S. Sim and S. Nakai). CAB International: Wallingford, UK. pp. 150-157.

Mecham, D. K. and H. S. Olcott. 1949. Phosvitin, the principal phosphoprotein of egg yolk. J. Am. Chem. Soc. 71:3670-3679.

Riemer, J., H. H. Hoepken, H. Czerwinska, S. R. Robinson, and R. Dringen. 2004. Colorimetric ferrozine-based assay for the quantitation of iron in cultured cells. Anal. Biochem. 331:370375 .
Shainkin, R. and G. E. Perlmann. 1971. Phosvitin, a Phosphoglycoprotein. J. Biol. Chem. 246:2278-2284.

Taborsky, G. 1963. Interaction between phosvitin and iron and its effect on a rearrangement of phosvitin structure. Biochemistry 2:266-271.

Taborsky, G. 1983. Phosvitin. Adv. Inorg. Biochem. 5:235-279.

Wallace, R. A. and J. P. Morgan. 1986. Isolation of phosvitin: retention of small molecular weight species and staining characteristics on electrophoretic gels. Anal. Biochem. 157:256-261.

Webb, J., J. S. Multani, P. Saltman, N. A. Beach, and H. B. Gray. 1973. Spectroscopic and magnetic studies of iron(III) phosvitins. Biochemistry 12:1797-1802. 